\title{
New double-staining technique for RNA and DNA measurement in marine phytoplankton
}

\author{
Elisa Berdalet ${ }^{1}$, Quay Dortch ${ }^{2}$ \\ ${ }^{1}$ Institut de Ciències del Mar, E-08039 Barcelona, Spain \\ ${ }^{2}$ Louisiana Universities Marine Consortium, LUMCON, Chauvin, Louisiana 70344, USA
}

\begin{abstract}
The use of RNA: DNA ratios as a biochemical indicator is hampered by the lack of simple and reliable methods for routine work. The technique presented here approaches this problem by using 2 fluorochromes: Hoechst 33258, which specifically reacts with DNA, and Thiazole Orange, which allows total nucleic acid estimation. Samples are homogenized in Tris- $\mathrm{Ca}^{2+}$ buffer which is also used in the fluorometric analysis. Subsequently, these fluorochromes are added to different subsamples of the same nucleic acid extract. Several extraction and analysis techniques were tested and an optimized procedure is described. The technique is simple and more sensitive than previously described methods for the determination of RNA and DNA in phytoplankton.
\end{abstract}

\section{INTRODUCTION}

RNA : DNA ratios have been used as a biochemical indicator of growth rates in a variety of marine organisms (Sutcliffe 1970, Buckley \& Lough 1987, Bulow 1987, Clemmesen 1987, 1988, Clarke et al. 1988, Raae et al. 1988. Mordy \& Carlson 1991), including phytoplankton (Dortch et al. 1983, 1985, Mordy \& Carlson 1991). Because of the chemical similarity of RNA and DNA, quantifying each separately by classical methods requires lengthy extractions. Further, the final quantification by spectrophotometric (ultraviolet absortion) and colorimetric methods (with orcinol for RNA and diphenylamine for DNA) is made difficult by low sensitivity and interference from extracting substances and many cellular components other than nucleic acids (see e.g. Herbert et al. 1971, Cattolico 1978). Greater sensitivity can be achieved through the use of fluorescent stains, but the available methods are still somewhat cumbersome, time-consuming and subject to some potential problems (Holm-Hansen et al. 1968, Thoresen et al. 1983, Clemmesen 1988).

For example, in a widely used method developed by Prasad et al. (1972), total nucleic acid is measured with ethidium bromide, which reacts with both DNA and RNA and produces a highly fluorescent compound. The RNA is then destroyed with the enzyme RNAse, and the fluorescence due to DNA is measured. RNA concentration is then calculated from the difference between total nucleic acids and DNA. The incubation procedure and all the various blanks slow the analysis procedure considerably. In addition, ethidium bromide has a relatively low quantum yield (Lee et al. 1986) and a high background fluorescence, which limits sensitivity. Finally, the most effective methods of extracting RNA and DNA are not necessarily compatible with subsequent use of an enzyme to remove RNA.

The purposes of this work were (1) to test the usefulness of specific fluorochromes for RNA and DNA in order to avoid the use of enzymatic digestion, and (2) to describe a reliable, simple extraction method for RNA and DNA.

Initially, we intended to investigate specific stains for RNA and DNA which have been reported recently in the literature: Hoechst 33258 and Hoechst 33342 (Loken 1980, Paul \& Myers 1982, Paul et al. 1985) for DNA, Pyronin Y (Tanke et al. 1980, Shapiro 1981) and Thiazole Orange (Lee et al. 1986) for RNA, and Acridine Orange, which can be made more sensitive to RNA or DNA by varying the dye concentration (Darzynkiewicz 1979, Kapuscinski et al. 1983). However, no stain was sufficiently specific for RNA, so an alternative approach using one dye for DNA and another for total nucleic acids (Clemmesen 1988, Mordy \& Carlson 1991) was considered. In this case, the criteria for choice of a stain for total nucleic acids were: (1) the fluorescence for RNA and DNA must be additive for a wide range of nucleic acid concen- 
trations; and (2) sensitivity to RNA must be high. Thus, in this paper we describe all the steps followed to establish the optimum analytical procedure.

\section{MATERIAL AND METHODS}

Chemicals and solutions. DNA Type I from calf thymus (D-5101), RNA Type III from baker's yeast (R7125), Hoechst 33342 (H342; B-2261), Hoechst 33258 (H258; B-2883), ethidium bromide (EB; E-8751), Tris ( $\mathrm{T}-1378$ ), the protease Pronase E (P5179) and lysozyme (L7001), sodium dodecyl sulfate (SDS; L4509) were provided by Sigma, St. Louis, MO, USA; high purity Acridine Orange (AO; A-1301) and Thiazole Orange (TO; T-1376), by Molecular Probes, Inc., Eugene, OR, USA; purified Pyronin Y (PY; \# 1082) and HEPES [N-(2-hydroxyethyl)piperazine$\mathrm{N}^{\prime}$-(2-ethenesulfonyl acid)] by Polysciences, Inc., Warrington, PA, USA.

All glassware, plastic Pasteur pipettes and pipette tips were carefully cleaned by sequentially soaking in $1 \mathrm{~N}$ sodium hydroxide $(\mathrm{NaOH}), 10 \%$ hydrochloric acid $(\mathrm{HCl})$ and $0.2 \mu \mathrm{m}$ filtered deionized distilled water (DDW), in order to avoid any nuclease contamination.

Table 1 shows the buffer and concentration used for each dye. Buffer phosphate (BP) of $0.125 \mathrm{M}$ was composed of $5.1 \mathrm{~g} \mathrm{KH}_{2} \mathrm{PO}_{4}$ and $30.18 \mathrm{~g} \mathrm{Na}_{2} \mathrm{HPO}_{4}$, brought to a final volume of 11 with DDW. In the phosphatebuffered saline (PBS), $1 \mathrm{l}$ solution contained $132.4 \mathrm{mg}$ $\mathrm{CaCl}_{2} \cdot 2 \mathrm{H}_{2} \mathrm{O}, \quad 0.2 \mathrm{~g} \mathrm{KCl}, 0.2 \mathrm{~g} \quad \mathrm{KH}_{2} \mathrm{PO}_{4}, \quad 0.1 \mathrm{~g}$ $\mathrm{MgCl} 6 \mathrm{H}_{2} \mathrm{O}, 8 \mathrm{~g} \mathrm{NaCl}, 1.15 \mathrm{~g} \mathrm{Na}_{2} \mathrm{HPO}_{4}$ and $744.4 \mathrm{mg}$
EDTA. HEPES buffer was composed of $8.775 \mathrm{~g} \mathrm{NaCl}$ $1^{-1}$ and $1.19 \mathrm{~g} \mathrm{HEPES} 1^{-1}$. Finally, 11 of Tris buffer solution was made up with $5.84 \mathrm{~g} \mathrm{NaCl}$ and $12.11 \mathrm{~g}$ Tris. The $\mathrm{pH}$ was 7.5 for all solutions (except those for Thiazole Orange referred to in Table 2; see below), and was adjusted before the solution was brought to final volume. All solutions were stored in the dark. In accordance with the literature, the stock and working solutions of $\mathrm{H} 342, \mathrm{H} 258$ and $\mathrm{EB}$ were kept at 0 to $4{ }^{\circ} \mathrm{C}$, and those of $\mathrm{AO}$ and $\mathrm{TO}$ at room temperature; the stock solution of PY was maintained at $0^{\circ} \mathrm{C}$ and the working solution at room temperature

In each experiment, nucleic acids and dyes were dissolved in the same buffer. Purity and concentration of the RNA and DNA stock solutions were checked by measuring their absorbance at 230, 260, 275, 280 and $310 \mathrm{~nm}$ (L. Cornudella pers. comm.). Nucleic acid solutions are stable for months if made with $0.2 \mu \mathrm{m}$ filtered DDW and kept at 0 to $4{ }^{\circ} \mathrm{C}$.

Procedure for testing suitability of a dye. In general, the sequence of operations was to: (1) find the optical properties of the dye (absorption, excitation, emission spectra) alone and upon binding to the nucleic acids; (2) measure the stability of the fluorescence; (3) run standard curves to determine sensitivity and linearity of fluorescence; (4) check the dye's specificity for RNA or DNA; (5) make dye-titration curves to determine appropriate dye concentrations; (6) determine the additivity for RNA and DNA when the dye stained both RNA and DNA.

All experiments were performed in a constant-volume, $3 \mathrm{ml}$ assay. Thus, we refer to the amount of nucleic acids and stains by weight in this fixed volume.

Table 1. Buffer and concentration used of the stock and working dye solutions examined. Buffer composition is detailed in 'Material and Methods' DDW: deionized distilled water; HEPES: $\mathrm{N}$-[2-hydroxylethyl]piperazine- $\mathrm{N}$-[2-ethenesulfonil acid]; PBS: phosphate-buffered saline; BP: buffer phosphate

\begin{tabular}{|c|c|c|c|c|c|}
\hline \multirow[t]{2}{*}{ Dye } & \multicolumn{2}{|c|}{ Stock solution } & \multicolumn{2}{|c|}{ Working solution } & \multirow[t]{2}{*}{ Source } \\
\hline & Buffer & Conc. & Buffer & Conc & \\
\hline Hoechst 33258 & DDW & $100 \mu \mathrm{M}$ & $\begin{array}{l}\text { PBS } \\
\text { Tris-Ca }{ }^{2+}\end{array}$ & $\begin{array}{l}1-10 \mu \mathrm{M} \\
1-10 \mu \mathrm{M}\end{array}$ & $\begin{array}{l}\text { Thoresen et al. (1983) } \\
\text { This study }\end{array}$ \\
\hline Hoechst 33342 & DDW & $100 \mu \mathrm{M}$ & $\begin{array}{l}\text { PBS } \\
\text { BP }\end{array}$ & $\begin{array}{l}1-10 \mu \mathrm{M} \\
1-10 \mu \mathrm{M}\end{array}$ & $\begin{array}{l}\text { Shapiro (1981) } \\
\text { This study }\end{array}$ \\
\hline Pyronin Y & $5 \mathrm{mM} \mathrm{HEPES}$ & $200 \mu \mathrm{M}$ & $5 \mathrm{mM}$ HEPES & $2 \mu \mathrm{M}$ & $\begin{array}{l}\text { Kapuscinski \& Darzynkiewicz } \\
\text { (1987) }\end{array}$ \\
\hline Acridine Orange & DDW & $1.58 \mathrm{mM}$ & DDW & $4 \mu \mathrm{M}$ & Kapuscinski et al. (1983) \\
\hline Ethidium bromide & & & $\begin{array}{l}\text { PBS } \\
\text { Tris-Ca }{ }^{2+} \\
\text { HEPES }\end{array}$ & $\begin{array}{l}20 \mu \mathrm{g} \mathrm{ml} \\
20 \mu \mathrm{g} \mathrm{ml} \\
20 \mu \mathrm{g} \mathrm{ml}\end{array}$ & $\begin{array}{l}\text { El-Hamalawi et al. (1975) } \\
\text { This study } \\
\text { This study }\end{array}$ \\
\hline Thiazole Orange & Ethanol & $1 \mathrm{mg} \mathrm{ml}^{-1}$ & $\begin{array}{l}\text { PBS } \\
\text { BP } \\
\text { Tris } \\
\text { HEPES }\end{array}$ & $\begin{array}{l}10 \mu \mathrm{g} \mathrm{ml}^{-1} \\
10 \mu \mathrm{gll}^{-1} \\
10 \mu \mathrm{g} \mathrm{ml} \mathrm{m}^{-1} \\
10 \mu \mathrm{g} \mathrm{ml} l^{-1}\end{array}$ & $\begin{array}{l}\text { Lee et al. (1986) } \\
\text { This study } \\
\text { This study } \\
\text { This study }\end{array}$ \\
\hline
\end{tabular}


Absortion spectra of the stains were obtained on a Varian DMS-80 UV-Visible spectrophotometer $10.2 \mathrm{~nm}$ resolution). Fluorescence spectra were obtained on a 430 Turner spectrofluorometer, $15 \mathrm{~nm}$ bandwidth. For several dyes, there was some overlap between the excitation and the emission spectra. To record the spectra, the excitation and emission wavelength were initially fixed at wavelengths other than the maxima referred to in the literature. Thus, for PY, the excitation spectrum (emission at $610 \mathrm{~nm}$ ) was recorded at 450 to $600 \mathrm{~nm}$, and the emission spectrum (excitation at $500 \mathrm{~nm}$ ) at 540 to $650 \mathrm{~nm}$. For TO, the excitation spectrum (emission at $560 \mathrm{~nm}$ ) was recorded at 400 to $560 \mathrm{~nm}$, and the emission spectrum (excitation at $490 \mathrm{~nm}$ ) at 500 to $720 \mathrm{~nm}$. In the case of $\mathrm{AO}$ several fluorescence spectra were performed with different dye: RNA ratios in order to find the specific emission for DNA which is related to RNA denaturation (Kapuscinski et al. 1983).

Titration curves were made by adding increasing amounts of the stains to fixed quantities of DNA or RNA ( 10 or $20 \mu \mathrm{g}$ or $<10 \mu \mathrm{g}$ ). When the dye alone had a high fluorescence (AO,EB), a blank titration was also performed by adding the stain to the buffer only. The amount of dye should be chosen from the titration curve in the range where dye saturation is reached for both DNA and RNA, i.e., where fluorescence is independent of dye concentration.

When a dye stained both RNA and DNA, it was necessary to check for individual RNA and DNA fluorescence additivity. This means that fluorescence due to the total nucleic acids present in the sample must equal that of the dye-RNA and dye-DNA individual fluorescences. Thus, standards were run containing RNA (or DNA) only, and containing RNA (or DNA) with increasing amounts of DNA (or RNA). The slopes of the standard curves should be the same and the intercepts should increase proportionally, if there is additivity. Total nucleic acid amounts were always between 0 and $20 \mu \mathrm{g}$

The possibility that staining DNA first with $\mathrm{H} 258$ or H342 would prevent DNA complexation with a second stain, so that the second stain would react only with RNA (Tanke et al. 1980, Shapiro 1981), was tested. Double staining was carried out by adding $\mathrm{AO}, \mathrm{PY}$ or EB after either Hoechst stain. However, the previous staining with Hoechst did not affect DNA binding by the other dyes.

Comparison of extraction methods. Once a combination of dyes utilizing $\mathrm{TO}$ and $\mathrm{H} 258$ was found to be suitable, and an assay procedure developed, that procedure was followed in experiments to test extraction procedures.

Efficacy of extraction was tested in 2 ways. (1) Samples from algal cultures of different phytoplankton groups were extracted by a variety of methods and compared. The methods which yielded the highest nucleic acid concentrations and least variability were rated highest. (2) Known amounts of concentrated RNA and DNA $\left(200 \mu \mathrm{g} \mathrm{ml}^{-1}\right.$ in $\left.0.1 \mathrm{M} \mathrm{NaCl}\right)$ were added to filtered algal samples, extracted by various methods, and the percentage recovery calculated.

Phytoplankton samples were vacuum filtered $(<100$ $\mathrm{mm} \mathrm{Hg})$ through precombusted $\left(350^{\circ} \mathrm{C}, 24 \mathrm{~h}\right)$ Whatman GF/F filters, and samples were processed immediately. The filter blanks were rinsed with filtered seawater and processed as the samples. The filters were transferred to a Potter-Elvenhjem tissue-homogenizing tube containing grinding buffer, ground for $2 \mathrm{~min}$ in ice, and decanted into a conical centrifuge tube. The grinding tube was rinsed with small amount of buffer and the final volume noted. Centrifugation was carried out at $2000 \times g$ for 5 min (refrigerated centrifugation is recommended, if possible). When necessary, the supernatant was decanted into another capped conical tube and centrifuged again. The extracts were stored on ice before processing. Standards were made up in the same solutions as the samples for each method.

In trichloroacetic acid (TCA) extractions, filters were ground for $2 \mathrm{~min}$ in $1 \mathrm{ml} 10 \%$ TCA and rinsed with $1 \mathrm{ml}$ of TCA. The homogenates were centrifuged for 5 min; after decanting, the pellet was resuspended in $1 \mathrm{ml} 1 \mathrm{~N} \mathrm{NaOH}$, mixed and left to settle for $5 \mathrm{~min}$. It was then neutralized immediately with $0.185 \mathrm{ml}$ of $4 \mathrm{M} \mathrm{HCl}$ to avoid hydrolysis of RNA by strong base, and the solution was made up to $3 \mathrm{ml}$ in Tris-Ca ${ }^{2+}$. Two additional centrifugations were necessary prior to analysis.

To check the effect of enzyme digestion after grinding in Tris- $\mathrm{Ca}^{2+}$, aliquots of the homogenates were transferred to tubes containing different amounts of protease $\left(0.0025,0.025,0.25\right.$ and $2.5 \mathrm{mg} \mathrm{ml}^{-1}$, final concentrations), lysozyme $(0.00125,0.0125,0.025$, $0.125,0.25,1.25 \mathrm{mg} \mathrm{ml}^{-1}$ ) or both, and incubated in a water bath at $37^{\circ} \mathrm{C}$. Incubation time was 20 min when only 1 enzyme was used. When both enzymes were assayed, after 10 min incubations with lysozyme, protease was added and the mixture was incubated for an additional $10 \mathrm{~min}$.

To test the reduction of RNAse activity by SDS, different amounts of this detergent were added before or after extraction of the nucleic acids in Tris- $\mathrm{Ca}^{2+}$ or Tris-Ca ${ }^{2+}+$ enzymes.

Phytoplankton cultures and sampling. The experimental species covered different phytoplankton groups. Thalassiosira sp. (Bacillariophyceae), Isochrysis galbana (Chrysophyceae) and Synechococcus sp. (Cyanobacteria) were provided by the Louisiana Universities Marine Consortium (LUMCON) culture col- 
lection; Prorocentrum micans (clone PROROIII, Dinophyceae), by Bigelow Laboratory for Ocean Sciences, ME, USA; Scrippsiella trochoidea (Dinophyceae), by The Laboratory, Marine Biological Association, UK, Heterocapsa sp. (Dinophyceae), by the Institut de Ciències del Mar, Barcelona, Spain. Batch cultures were started in f/2 media (Guillard 1975) with silicate only added for diatoms, at constant temperature $\left(17 \pm 1^{\circ} \mathrm{C}\right)$ under a $12 \mathrm{~h}$ light: $12 \mathrm{~h}$ dark cycle with a light intensity of $150 \mu \mathrm{mol} \mathrm{m} \mathrm{m}^{-2} \mathrm{~s}^{-1}$. Daily cell counts were performed using a Palmer-Malony chamber, and the cultures were kept exponentially growing by dilution with new media.

Natural samples. Natural seawater samples were collected in February 1990 from the Catalan Sea (western Mediterranean) during the FRONTS-90 cruise (Berdalet et al. unpubl. data). This is an oligotrophic zone which displayed a subsurface chlorophyll maximum at about 20 to $40 \mathrm{~m}$. Samples (4 1 ) from 6 selected depths were obtained with 301 Niskin bottles, prefiltered through a $234 \mu \mathrm{m}$ mesh, filtered in duplicate through precombusted Whatman GF/F filters and immediately frozen in liquid nitrogen. Processing was performed later in the laboratory.

Nucleic acid measurement and calculations. Three $0.5 \mathrm{ml}$ aliquots of the supernatant of the extract for each test treatment were transferred to 3 test tubes. The ratio of sample to total volume was kept low to minimize interference that would occur if chlorophyll concentrations in the assay were high (Thoresen et al. 1983, Mordy \& Carlson 1991). The first tube, containing $2.5 \mathrm{ml}$ of Tris- $\mathrm{Ca}^{2+}$ buffer, was used as the pigment blank; readings were carried out at $360 \mathrm{~nm}$ excitation wavelength and $460 \mathrm{~nm}$ emission wavelength for $\mathrm{H} 258$, and at 511 and $533 \mathrm{~nm}$ for TO. The second tube, with $1 \mathrm{ml}$. of 5.62 uM H258 and $1.5 \mathrm{ml}$ of buffer, allowed DNA quantification at 360 and $460 \mathrm{~nm}$. In the third tube, $0.55 \mathrm{ml}$ of $21 \mu \mathrm{M}$ TO and $1.45 \mathrm{ml}$ of buffer were added, and readings at 511 and $533 \mathrm{~nm}$ yielded total DNA+RNA content. Concentrations were calculated from standard curves made up in exactly the same way as the samples (including a pre-rinsed filter with filtered seawater). DNA concentration was determined from the H258-DNA calibration curve, and this value was used to calculate the TO fluorescence due to DNA (TO-DNA). The TO fluorescence due to RNA (TORNA) was estimated by substracting this value from the total TO fluorescence (DNA and RNA). RNA concentration was then calculated from the TO-RNA calibration curve. The averaged fluorescence of several filter blanks (processed as samples) was subtracted from the homogenate fluorescence with each stain (see Fig. 5). In extractions with added standard nucleic acids, percentage recovery was calculated after corrections for contributions by filters and cells.

\section{RESULTS}

\section{Choice of a suitable stain}

Both H342 and H258 exhibited high specificity for DNA, very low: fluorescence background, and a stable fluorescence product (up to $70 \mathrm{~min}$ ). Their excitation and emission maxima after binding DNA were 360 and $460 \mathrm{~nm}$ respectively $(360,460)$. $\mathrm{PY}, \mathrm{AO}, \mathrm{EB}$ and $\mathrm{TO}$ stained both DNA and RNA. However, PY - with a fluorescence peak at $(548,563) \mathrm{nm}$ - showed strong fluorescence quenching after binding RNA and DNA (not shown), so that fluorescence vs nucleic acid concentration had a negative slope. Thus, PY was not considered further According to the literature, $\mathrm{AO}$ has metachromatic properties which could allow differentiation between DNA and RNA by using different dye concentrations (Darzynkiewicz et al. 1983). Briefly, at high concentrations AO should specifically bind RNA and show red fluorescence (wavelength emission maximum $>600 \mathrm{~mm}$ ) and at low concentrations it should bind DNA and exhibit green fluorescence $(530 \mathrm{~nm})$. Nevertheless, for a wide range of RNA: dye ratios, no fluorescence peak other than that at $(494,525) \mathrm{nm}$ for both DNA and RNA was obtained in our experiments. Since it was not possible to measure RNA and DNA. separately and since $A O$ had high background fluorescence, no further experiments were conducted with AO. TO, which has negligible background fluorescence, a large fluorescence enhancement after binding to the nucleic acids at $(511,533) \mathrm{nm}$ (Fig. 1) and constant fluorescence over time, was the first choice for further consideration. EB, the widely used

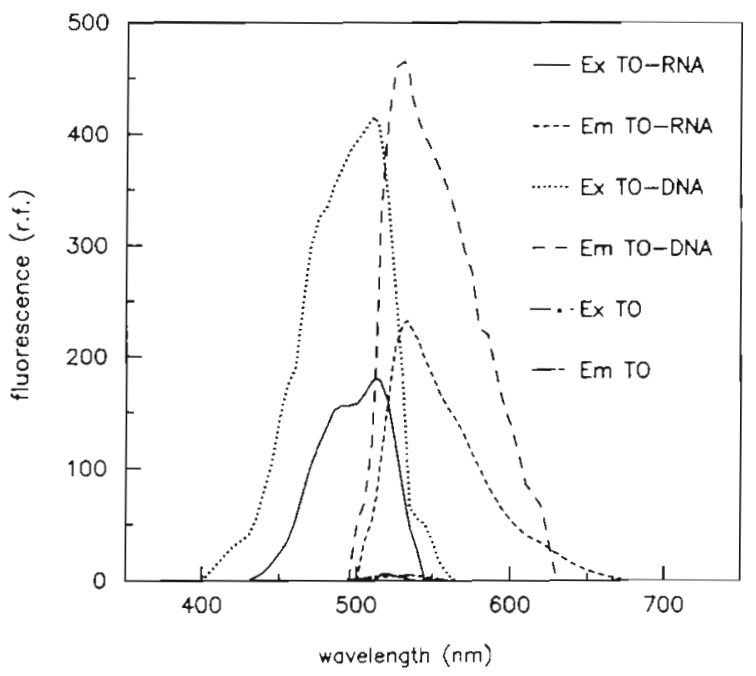

Fig. 1. Excitation (Ex) and emission (Em) spectra of Thrazole Orange alone (TO) and with DNA (TO-DNA) and RNA (TORNA) (RNA $50 \mu \mathrm{g} \mathrm{ml}^{-1}$. DNA $50 \mu \mathrm{g} \mathrm{ml}^{-1}$, TO $5 \mu \mathrm{g} \mathrm{ml}{ }^{1}$ ). r.f. relative fluorescence 

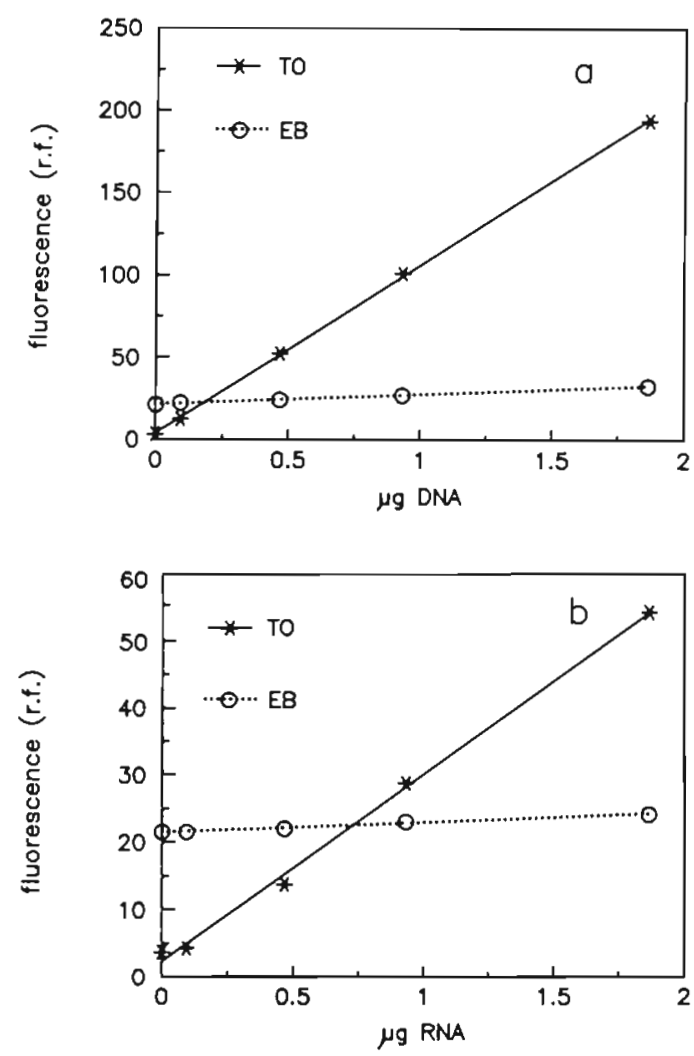

Fig. 2. Comparison of sensitivity and blank fluorescence from standard curves of Thiazole Orange (TO) and ethidium bromide (EB) with (a) DNA and (b) RNA, in Tris- $\mathrm{Ca}^{2+}$. Nucleic acid amounts are those in the $3 \mathrm{ml}$ final volume of the assay. (a) TO-DNA standard: Fluor $=3.82+102.55$ ( $\mu \mathrm{g}$ DNA), $\mathrm{r}^{2}=$ 0.999888 ; EB-DNA standard: Fluor $=21.58+6.02(\mu \mathrm{g} D N A)$. $r^{2}=0.997451$ (b) TO-RNA standard: Fluor $=2.30+22.63(\mu \mathrm{g}$ RNA), $\mathrm{r}^{2}=0.997332 ;$ EB-RNA standard: Fluor $=21.54+1.19$ ( $\mu$ g RNA), $r^{2}=0.986607$. (Fluor: fluorescence response. All fluorescence values are presented at the same scale; r.f.: relative fluorescence)

stain for DNA and RNA quantification, presented a high fluorescence background, as well as a low quantum yield compared with $\mathrm{AO}$ and especially with $\mathrm{TO}$ (Fig. 2). EB showed 2 fluorescence peaks, $(345,620) \mathrm{nm}$ and $(520,620) \mathrm{nm}$.

Although no stain was specific for RNA, the good fluorescence properties of TO (high sensitivity, high quantum yield and low fluorescence background) indicated that it might be a better stain for total nucleic acids than was EB. Initially, the major problem with TO was poor additivity of fluorescence for RNA and DNA standard curves; the reason for this was that fluorescence was dependent on both the TO and nucleic acid concentrations under the initial assay conditions. Ideally, for a given nucleic acid concentration, fluorescence should be independent of TO concentration over a wide range of $\mathrm{TO}$ and nucleic acid concentrations. Due to the many advantages of TO, a series of experiments
Table 2. Buffers used in Thiazole Orange (TO) titrations with RNA and DNA in order to find the experimental conditions yielding the largest TO concentration range over which total nucleic acid fluorescence reflected fluorescence of RNA + DNA individually. Buffer abbreviations as in Table 1

\begin{tabular}{ccc}
\hline Buffer & $\mathrm{pH}$ & EDTA \\
\hline \multirow{2}{*}{ PBS } & 7.5 & $0.002 \mathrm{M}$ \\
& 7.5 & $0.1 \mathrm{M}$ \\
& 6.5 & $0.002 \mathrm{M}$ \\
& 6.5 & $0.1 \mathrm{M}$ \\
BP & 8.5 & - \\
Tris & \\
HEPES & 7.5 & - \\
a Included experiments with 21 combinations of $\mathrm{K}^{+}, \mathrm{Ca}^{2+}$ \\
and Mg ${ }^{2+}$ concentrations from 1 to $100 \times$ standard concen- \\
trations (see 'Results - Choice of a suitable stain')
\end{tabular}

was carried out testing different assay conditions (Table 2) to minimize the effect of TO concentrations.

The first experiments examined the effect of different buffers and $\mathrm{pH}$ levels (Table 2) on the fluorescence produced when a constant amount of RNA was mixed with increasing concentrations of TO (Fig. 3a). Some buffers, such as Tris and BP, resulted in high fluorescence yields, but were unsuitable because fluorescence was highly dependent on TO concentrations. With PBS, although the fluorescence yield was lower, fluorescence was much less dependent on TO concentrations. Similar results were obtained for DNA. PBS differs from $\mathrm{BP}$ in that it contains 3 cations $\left(\mathrm{K}^{+}, \mathrm{Ca}^{2+}\right.$ and $\left.\mathrm{Mg}^{2+}\right)$, suggesting that the fluorescence of TO-RNA and TODNA complexes was sensitive to at least 1 of these cations.

The influence of these cations individually and together at different concentrations was studied for 21 combinations in Tris buffer (Table 2), chosen because of its high fluorescence yield. The presence of all 3 cations still decreased the fluorescence yield, but tended to flatten the titration curve (Fig. 3a). The flattest curve for both DNA and RNA was obtained with Tris buffer containing $132.4 \mathrm{mg}$ of $\mathrm{CaCl}_{2} \cdot 2 \mathrm{H}_{2} \mathrm{O}$ in Tris buffer (hereafter referred to as Tris- $\mathrm{Ca}^{2+}$ ). With this buffer fluorescence was independent of TO concentration over a wide range of TO, RNA and DNA concentrations (Fig. 3b), resulting in linear standard curves, additivity, and high sensitivity (Fig. 4).

In summary, the experiments described above led us to adopt a combination of $\mathrm{H} 258$ (for DNA determination) and TO (for DNA + RNA determination), both made up in Tris- $\mathrm{Ca}^{2+}$ buffer, $\mathrm{pH} 7.5$, as outlined in Fig. 5. The amount of $\mathrm{H} 258$ was fixed from the corresponding titration curve (not shown). The volume of the aliquot $(0.5 \mathrm{ml})$ was also chosen after testing a range of 0.25 to $1 \mathrm{ml}$ (not shown). 

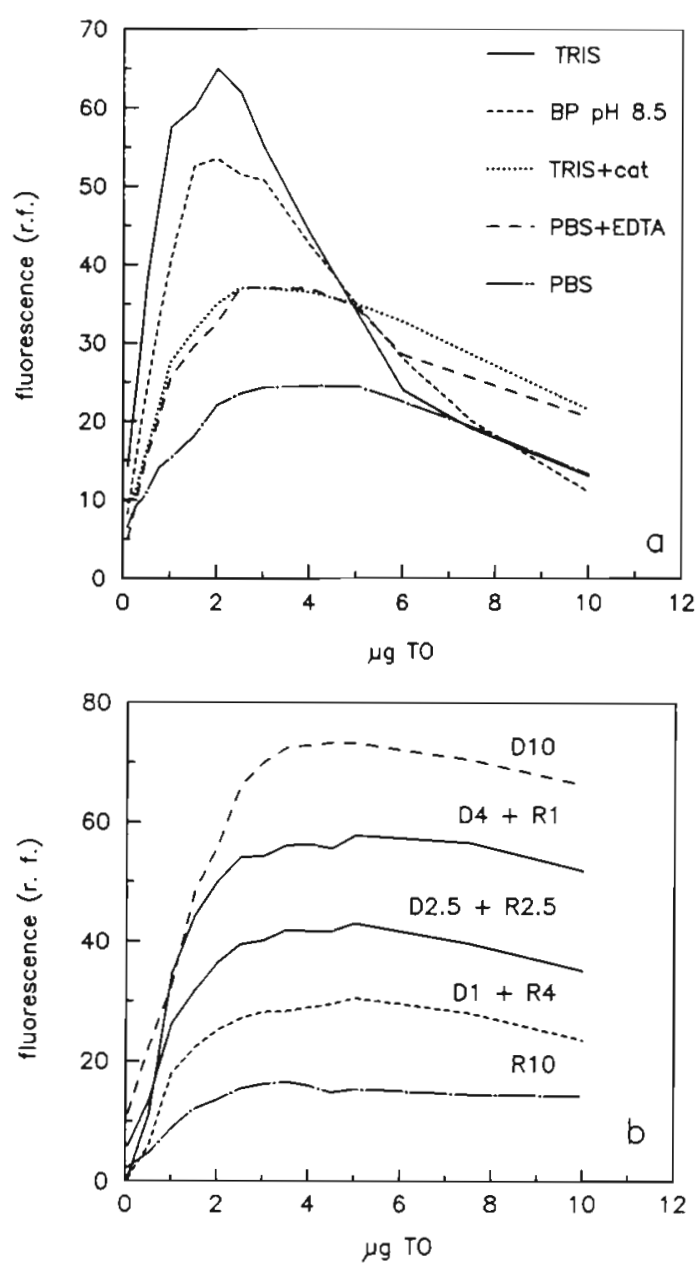

Fig. 3. Thiazole Orange (TO) titration curves. (a) Titration of $10 \mu \mathrm{g}$ RNA with TO in $3 \mathrm{ml}$ of phosphate-buffered saline, $\mathrm{pH}$ 7.5 (PBS), and PBS with 0.1 M EDTA at the same $\mathrm{pH}$ (PBS + EDTA); in buffer phosphate, pH 8.5 (BP pH 8.5); in Tris (Tris); and in Tris with the 3 cations $\mathrm{Ca}^{2+}, \mathrm{Mg}^{2+}$ and $\mathrm{K}^{+}$ (Tris + cat) at the same amount as in the PBS buffer. (b) Titration of nucleic acids with $\mathrm{TO}$ in Tris- $\mathrm{Ca}^{2+}$ for various amounts and combinations of RNA and DNA. D: DNA; R: RNA; number $=$ no. of $\mu \mathrm{g}$ of each

\section{Choice of extraction method}

Triplicate samples of 6 cultured phytoplankton species were filtered and extracted with DDW, Tris$\mathrm{Ca}^{2+}$ buffer, $10 \%$ TCA, and 0.01 and $0.001 \%$ SDS (final concentration) as grinding solutions (Table 3 ). Concentrations of RNA and DNA were calculated from standard curves made up to match each extraction method. Since Tris- $\mathrm{Ca}^{2+}$ was the buffer of choice for the analysis (see above), it was used as the control against which the other solutions were compared. No method gave consistently better results than did use of Tris- $\mathrm{Ca}^{2+}$. In particular, TCA, which readily precipitates protein and nucleic acids and was expected to

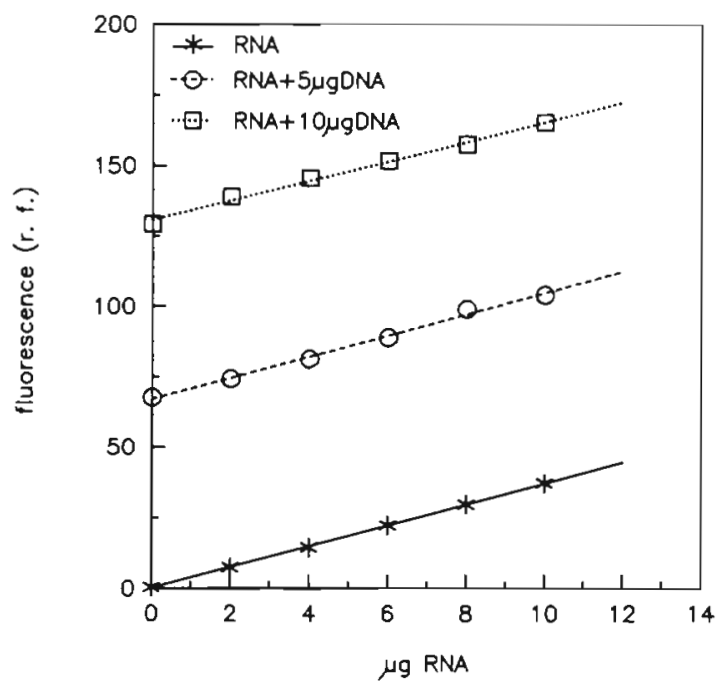

Fig. 4. Sample standard curves of RNA and RNA+DNA (in $3 \mathrm{ml}$ Tris- $\mathrm{Ca}^{2+}$ ) with $5.5 \mu \mathrm{g}$ Thiazole Orange

be the best extraction medium, gave very poor results for both DNA and RNA.

As can be seen in Table 4, use of lysozyme or protease always decreased the amount of RNA extracted and in general increased only slightly the DNA yield.

The addition of $0.01 \%$ SDS after extraction with Tris- $\mathrm{Ca}^{2+}$, and with and without incubation with enzymes, was supposed to inactivate RNAses (Clarke et al. 1988, Kumar et al. 1988) and increase the yield of RNA. There was no effect in Thalassiosira sp. and Heterocapsa sp., but in Isochrysis galbana the amount of RNA extracted was 3 times that of the control (data not shown). Grinding in $0.01 \%$ SDS also enhanced RNA extraction in I. galbana by a factor of 3 (Table 3).

The percentage recovery of known amounts of RNA and DNA added to filtered phytoplankton samples was determined for 3 extraction methods (Table 5). Only extraction with Tris-Ca ${ }^{2+}$ gave recoveries near $100 \%$. The percentage recoveries with Tris- $\mathrm{Ca}^{2+}$ and $0.01 \%$ SDS were determined using Isochrysis galbana; the very low DNA recovery, and RNA recovery $>100 \%$, explain the very high apparent RNA concentrations obtained for this species when SDS is used in the extraction

Thus it was concluded that a simple extraction method, as outlined in Fig. 5, yields the best results.

\section{Sensitivity}

Using standards, the smallest amounts of nucleic acids that could be detected with certainty were ca $25 \mathrm{ng}$ of RNA using TO, $10 \mathrm{ng}$ of DNA using TO and $25 \mathrm{ng}$ of DNA using H258, in the $3 \mathrm{ml}$ assay (i.e. 8.3, 3.3 and $8.3 \mathrm{ng} \mathrm{ml} \mathrm{ml}^{-1}$, respectively). This detection limit 


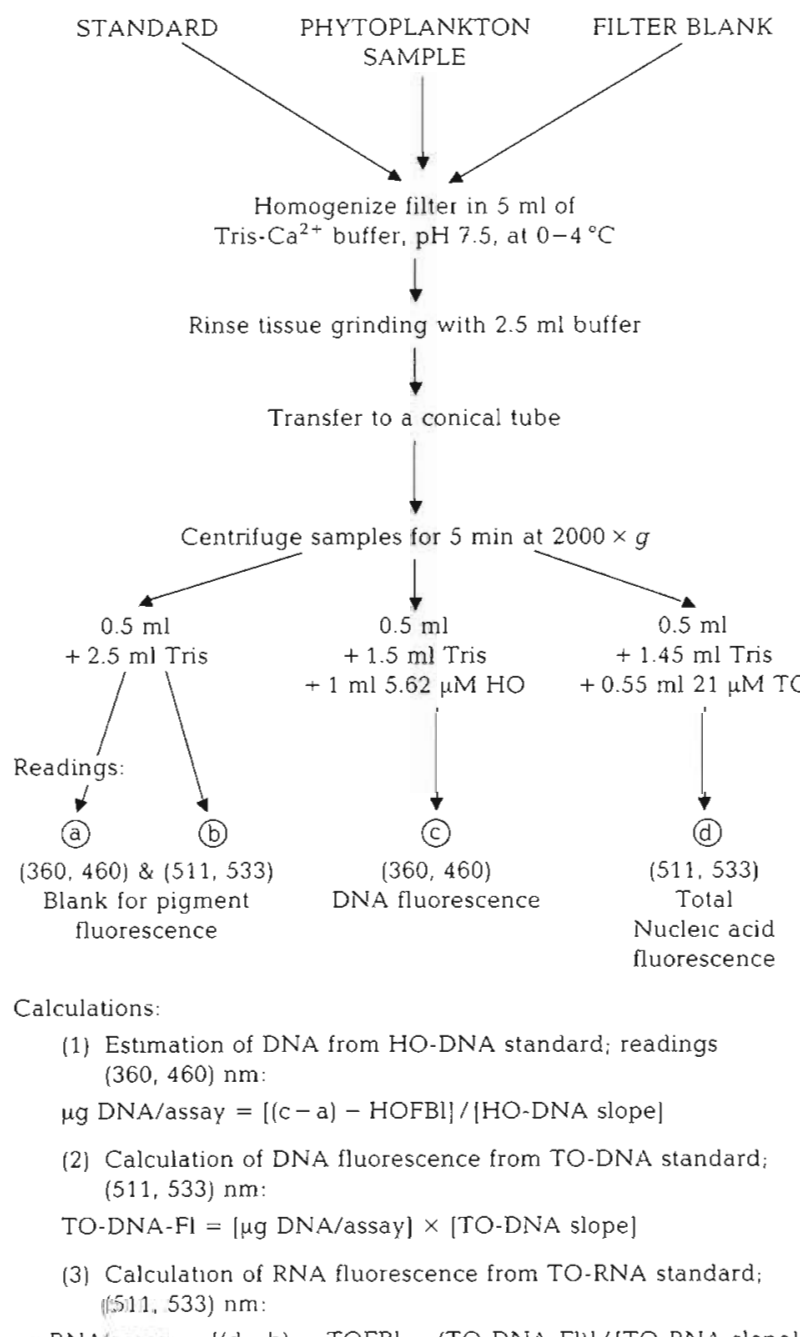

ug RNA/assay $=\mid(d-b)-$ TOFB $\mid-($ TO-DNA-F $) \mid /($ TO-RNA slope $]$

Fig. 5. Final recommended procedure for sample treatment. HOFBI and TOFBl refer to the averaged $(c-a)$ and $(d-b)$ fluorescence contribution by several filter blanks processed as samples. HO: Hoechst dye; TO: Thiazole Orange

allowed measurements of RNA and DNA at $100 \mathrm{~m}$ depth (Fig. 6) in an oligotrophic area $(0.04 \mu \mathrm{g}$ chlorophyll $a^{-1}$ ) of the western Mediterranean Sea, after filtering $4 \mathrm{l}$.

\section{DISCUSSION}

The experiments performed with the 2 bisbenzimidazolic dyes, H258 and H342, confirmed their high specificity for DNA, low fluorescence background, high fluorescence enhancement upon binding DNA (Steiner \& Sternberg 1979), and good stoichiometry for DNA quantification (Loken 1980). Either of them would be appropriate for DNA quantification, but we chose H258 because it has been used previously to quantify DNA in

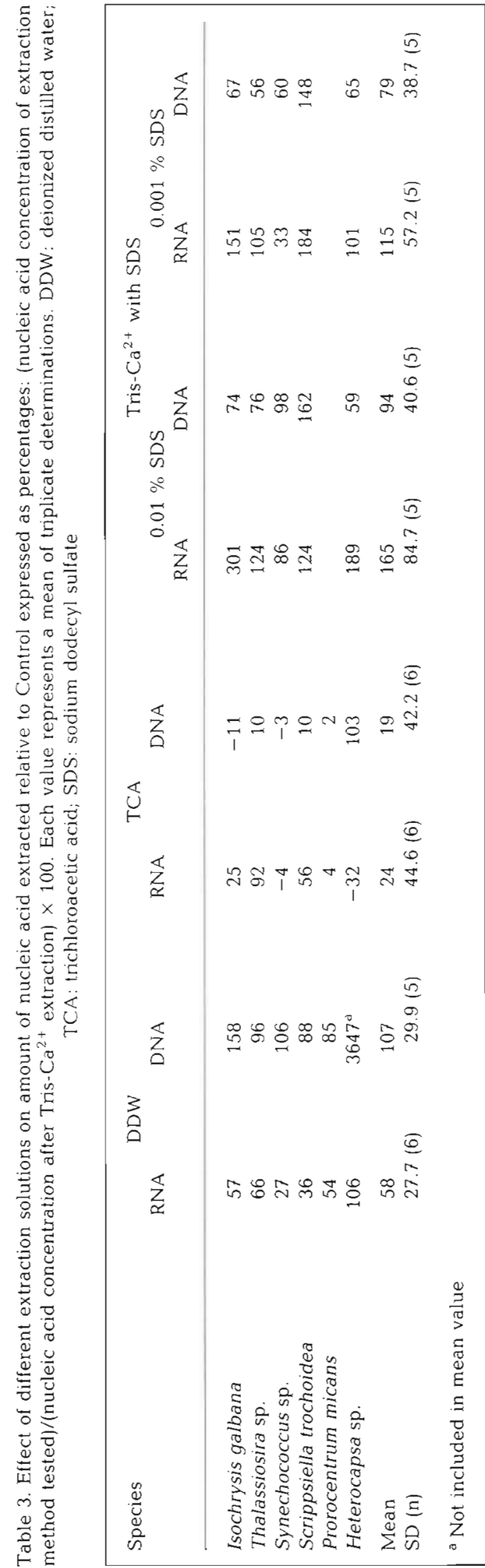


Table 4. Effect of enzyme digestion on RNA and DNA extraction relative to control (\% Control), calculated as in Table 3. Data were combined for experiments with no SDS (sodium dodecyl sulfate) added or $0.01 \%$ SDS (final concentration) added after enzyme digestion

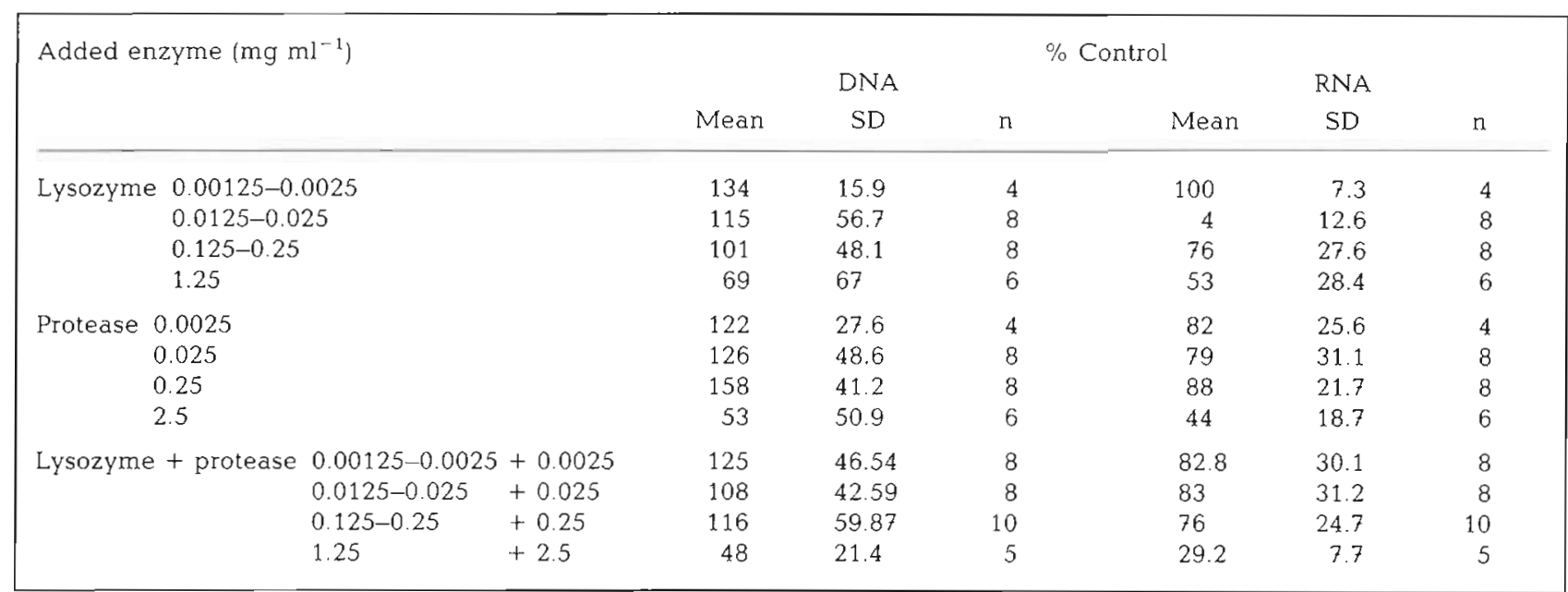

Table 5. \% Recovery of RNA and DNA added to filtered samples of phytoplankton cultures, using various extraction solutions. SDS: sodium dodecyl sulfate; TCA: trichloroacetic acid

\begin{tabular}{|c|c|c|c|c|c|c|}
\hline \multirow[t]{3}{*}{ Extraction solution } & \multicolumn{6}{|c|}{$\%$ Recovery } \\
\hline & \multicolumn{3}{|c|}{ DNA } & \multicolumn{3}{|c|}{ RNA } \\
\hline & Mean & $\mathrm{SD}$ & $\mathrm{n}$ & Mean & $\mathrm{SD}$ & n \\
\hline Tris- $\mathrm{Ca}^{2+}$ & 94 & 60.8 & 12 & 82 & 16.5 & 12 \\
\hline Tris-Ca ${ }^{2+}$ with $0.01 \%$ SDS & 0 & 82 & 4 & 139 & 14.6 & 4 \\
\hline $10 \%$ TCA & 10 & 130 & 12 & 25 & 23.0 & 12 \\
\hline
\end{tabular}

marine phytoplankton (Paul \& Myers 1982, Paul et al. 1985, Mordy \& Carlson 1991). The concentrations used (in the range of $10 \mu \mathrm{m}$ ) ensure DNA specificity for adenine-thymine rich DNA, according to many spectral studies (Bontemps et al. 1975, Latt \& Stetten 1976, Steiner \& Sternberg 1979, Sandhu et al. 1985, Stokke \& Steen 1985, Watson et al. 1985).

It was surprising that RNA specificity was not achieved by any of the fluorochromes, as expected from the literature. Among the dyes which simultaneously stained DNA and RNA, PY and AO were quickly discarded. PY had been reported to specifically stain RNA in combination with DNA-specific stains, namely H342 (Tanke et al. 1980, Shapiro 1981). Nevertheless, the considerable fluorescence-quenching of PY by increasing amounts of RNA added (due to the guanine bases, according to Darzynkiewicz et al. 1987 and Kapuscinski \& Darzynkiewicz 1987) was a major limitation. The main interest in $\mathrm{AO}$ was the possibility of distinguishing between DNA and RNA based on the metachromatic properties of the dye (Darzynkiewicz 1979, Darzynkiewicz et al. 1983). However, the excitation/emission spectra for RNA and DNA were identical, and all the experimental dye:RNA ratios yielded the same green fluorescence emission.
The other 2 stains, EB and TO, showed more potential for the simultaneous quantification of RNA and DNA. EB, in combination with $\mathrm{H} 258$, was developed by Clemmesen (1988). Nevertheless, EB has a high

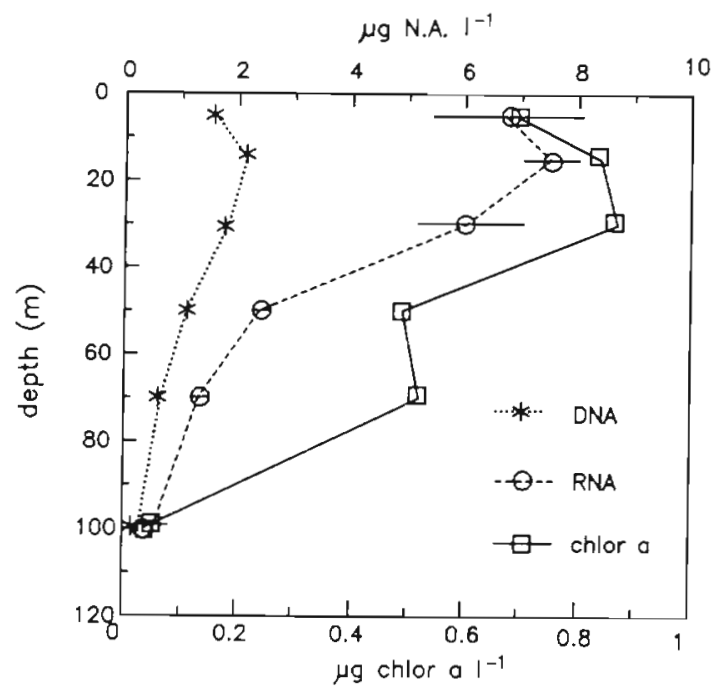

Fig. 6. Depth profiles of DNA and RNA (N.A.: nucleic acid; means \pm SEM, $\mathrm{n}=2$ or 3 ) and chlorophyll a (chlor a) in natural samples from one of the stations of the FRONTS-90 cruise in the western Mediterranean Sea 
fluorescence background and a relatively low quantum yield compared to $\mathrm{TO}$; this results in lower sensitivity. As shown in Fig. 2, the fluorescence yield of TO after binding both DNA and RNA was about 20 -fold that of EB, which represents a considerable increase in sensitivity.

The scarcity of information about TO (Lee et al. 1986. Makler et al. 1987) forced us to determine the optimum conditions for its use. Among the buffers assayed (Table 2), the best was Tris- $\mathrm{Ca}^{2+}$. For both DNA and RNA, fluorescence saturation was reached at $\geq 4 \mu \mathrm{g}$ of TO per sample; for TO amounts $>6$ to $8 \mu \mathrm{g}$, fluorescence decreased steadily (Fig. 3b). A fixed amount of $5.5 \mu \mathrm{g}$ TO in the $3 \mathrm{ml}$ assay allowed additivity over a wide range of nucleic acid concentrations, as indicated by the constant slopes and additive fluorescence of the $y$-intercepts of the standard curves (Fig. 4). This is crucial for the present method, because RNA must be estimated by subtraction after estimation of a sample's DNA content.

There is always a problem in choosing a standard for analysis of macromolecules, because of their wide range of composition and structure. For RNA and DNA, variations may arise because reactivity and subsequent fluorescence are dependent on base composition (as well as on nucleic acid conformation; Mordy \& Carlson 1991). While the base composition of algae can vary over a wide range (Sober 1970, Green 1974, PuiseuxDao 1981), Green (1974) concludes that most species fall between 50 and $65 \%$ guanine + cytosine. Since a $29 \%$ change in base composition is required in order to produce a $50 \%$ change in fluorescence with $\mathrm{H} 258$ (Comings \& Drets 1976), the effect will be minimal for H258 in comparison with other DNA stains (Comings \& Drets 1976). However, there are no data concerning the effect of RNA base composition on TO fluorescence.

It was initially expected that the highest yields and best extraction efficiencies would be obtained with TCA, which is used routinely to precipitate RNA and DNA in a variety of applications in marine science (e.g. Li et al. 1980, Karl et al. 1981, Fuhrman \& Azam 1982, Carman et al. 1988), or with SDS, which disrupts membranes and specifically inhibits enzymes which degrade nucleic acids (Clarke et al. 1988, Kumar et al. 1988). However, of the extraction solutions and procedures tested, the best recovery and lowest variability was obtained with Tris-Ca ${ }^{2+}$ buffer. No other extraction method gave consistently higher nucleic acid yields, including use of enzymes such as proteases (Thoresen et al, 1983, Mordy \& Carlson 1991) and lysozyme, which catalyzes the hydrolysis of glycosidic bonds. Avoiding the use of enzymes (which need incubation), SDS (a strong detergent which produces many bubbles in the solution) or TCA (which includes many rinsing steps) makes the extraction procedure faster and sim- pler. Another important advantage is that extraction and analysis can be performed in the same solution.

One reason these experiments were undertaken was to develop a method of extracting and analyzing DNA from the condensed dinokaryon nucleus. Good agreement between our results and those for DNA content of Gymnodinium nelsonii (Berdalet unpubl. data), Prorocentrum micans and Scrippsiella trochoidea (Rizzo \& Nooden 1973. Haapala \& Soyer 1974) suggest that we were successful. The same field data obtained using this technique were part of a larger study of surfacewater RNA/DNA and deep chlorophyll maximum in the western Mediterranean Sea. Since RNA/DNA measurements, like all chemical and biochemical indicators used in biological oceanography, can only be interpreted in conjunction with other field data, a more thorough analysis of the complete data set will be presented elsewhere.

In summary, the technique presented here is simple and rapid and keeps sample manipulation to a minimum. The method is more sensitive than previously described techniques which used ethidium bromide (Thoresen et al. 1983, Clemmesen 1988) and is similar to that developed by Mordy \& Carlson (1991) with ethidium homodimer. We expect that it will enhance the usefulness of biochemical indices such as RNA: DNA ratios (Dortch et al. 1983, 1985, Bulow 1987) in physiological studies of marine phytoplankton.

Acknowledgements. We are grateful to L. Cornudella, M. Latasa, C. Marrasé, C. Pedrós-Alió and E. Saiz for their comments, and to M. Alcaraz and M. Estrada who reviewed the manuscript. We thank C. Mordy and D. J. Carlson for access to their manuscript (Mordy \& Carlson 1991) and for cooperating in publishing both articles simultaneously. We also thank Louisiana Universities Marine Consortium, Louisiana, and Institut de Ciències del Mar, Barcelona. E.B. was supported by the FPI fellowship from the Ministerio de Educación $y$ Ciencia de España, funds from Programa Fronts MAR880252, CYCIT, CSIC and the Comissio Interdepartamental per a la Recerca i Innovació Tecnològica, CIRIT, de la Generalitat de Catalunya

\section{LITERATURE CITED}

Bontemps, J., Houssier, C., Fredericq, E. (1975). Physicochemical study of the complexes of Hoechst 33258 with DNA and nucleohistone. Nucleic acids Res. 2: 971-984

Buckley, L. J., Lough, R. G. (1987). Recent growth, biochemical compositon, and prey field of larval haddock (Melanogrammus aeglefinus) and Atlantic cod (Gadus morhua) on Georges Bank. Can. J. Fish. Aquat. Sci. 44: 14-25

Bulow, F. J. (1987). RNA-DNA ratios as indicators of growth in fish: a review. In: Summerfelt, R. C., Hall, G. E. (eds.). The age and growth of fish. Iowa State Univ. Press, Ames, Iowa, p. 45-64

Carman, K. R., Dobbs, F. C., Guckers, J. B. (1988). Consequences of thymidine catabolism for estimates of bacterial 
production: an example for a coastal marine sediment. Limnol. Oceanogr. 33 (6): 1595-1606

Cattolico, R. A. (1978). Nucleic acids. In: Hellebust, J. A., Craigie, J. S. (eds.) Handbook of physiological methods, Vol. II, Physiological and biochemical methods. Cambridge University Press, Cambridge, p. 81-90

Clarke, A., Rodhouse, P. G., Holmes, L. J., Pascoe, P. L. (1988). Growth rate and nucleic acid ratio in cultured cuttle fish Sepia officinalis (Mollusca: Cephalopoda). J. exp. mar. Biol. Ecol. 133: 229-240

Clemmesen, C. (1987). Laboratory studies on RNA/DNA ratios of starved and fed herring (Clupea harengus) and turbot (Scophthalmus maximus) larvae. J. Cons. int. Explor. Mer 43: $122-128$

Clemmesen, C. (1988). A RNA and DNA fluorescence technique to evaluate the nutritional condition of individual marine fish larvae. Meeresforsch. 32: 134-143

Comings, D. E., Drets, M. E. (1976). Mechanisms of chromosomes adequate to account for quinacrine, Hoechst 33258 and daudomycine banding. Chromosoma 56: 199-211

Darzynkiewicz, Z. (1979). Acridine Orange as a molecular probe in studies of nucleic acids in situ. In: Melamed, M. R., Mullaney, P. F., Mendelsohn, M. L. (eds.). Flow cytometry and sorting. J. Wiley \& Sons, New York, p. 285-316

Darzynkiewicz, Z., Evenson, D., Kapuscinski, Z., Melamed, M. R. (1983). Denaturation of RNA and DNA in situ induced by Acridine Orange. Expl. Cell Res. 148: 31-46

Darzynkiewicz, Z., Kapuscinski, J., Traganos, F., Crissman, H. A. (1987). Application of Pyronin $Y(G)$ in cytochemistry of nucleic acids. Cytometry 8: 138-145

Dortch, Q. F., Clayton, J. R., Jr., Thoresen, S. S., Ahmed, S. I. (1985). Nitrogen storage and the use of biochemical indices to assess nitrogen deficiency and growth rate in natural plankton populations. J. mar. Res. 43: 437-464

Dortch, Q. F., Roberts, T L., Clayton, J. R., Jr., Ahmed, S. I. (1983). RNA/DNA ratios and DNA concentrations as indicators of growth rate and biomass in planktonic marine organisms. Mar. Ecol. Prog. Ser. 13: 67-71

El-Hamalawi, A. R.-A., Thomson, J. S., Barker, G. R. (1975). The fluorometric determination of the nucleic acids in pea seeds by use of Ethidium Bromide complexes. Analyt Biochem. 67: 384-391

Fuhrman, J. A., Azam, F. (1982). Thymidine incorporation as a measure of heterotrophic bacterioplankton production in marine surface waters: evaluation and field results. Mar. Biol. 66: 109-120

Green, B. R. (1974). Nucleic acids and their metabolism. In Steward, W. D. P. (ed ) Algal physiology and biochemistry, Chap. 10. Blackwell Scientific Publications, Oxford, p. $281-313$

Guillard, R. R. L. (1975). Culture of phytoplankton for feeding marine invertebrates. In: Smith, W L., Chanley, M. H (eds.) Culture of manne invertebrate animals. Plenum Press, New York, p. 29-60

Haapala, O. K., Soyer, M.-O. (1974). A.bsence of longitudinal differentiation of a dinoflagellate (Prorocentrum micans) chomosome. Hereditas 78: 141-145

Herbert, D., Phipps, P. J., Strange, R. E. (1971). Chemical analysis of microbial cells. In: Norris, J. R., Ribbons, D. W (eds.) Methods in microbiology. Academic Press, London p. 308-328

Holm-Hansen, O., Sutcliffe, W. H., Jr., Sharp, J. (1968). Measurement of deoxyribonucleic acid in the ocean and its ecological significance. Limnol. Oceanogr. 13: 507-514

Kapuscinski, J., Darzynkiewicz, Z. (1987). Interactions of Pyronin $Y(G)$ with nucleic acids. Cytometry 8: 129-137

Kapuscinski, J., Darzynkiewicz, Z., Melamed, M. R. (1983)
Interactions of Acridine Orange with nucleic acids Biochem. Pharmac. 32 (24): 3679-3694

Karl, D. M., Winn, C. D., Wong, D. C. L. (1981). RNA synthesis as a measure of microbial growth in aquatic environments I. Evaluation, verification, and optimization of methods Mar. Biol. 64: 1-12

Kumar, S., Degnan, B. M., Ross, I. L., Hawkins, C. J. (1988) Isolation of DNA and RNA from ascidians. Mar. Biol. 98: 95-100

Latt, S. A., Stetten, G. (1976). Spectral studies on 33258 Hoechst and related bisbenzimidazole dyes useful for fluorescence detection of deoxyribonucleic acid synthesis J. Histochem. Cytochem. 24: 24-33

Lee, L. G., Chen, C.-H., Chiu, L. A. (1986). Thiazole Orange: a new dye for reticulocyte analysis. Chytometry 7: 508-517

Li, W. K. W., Glover, H. E., Morris, I. (1980). Physiology of carbon photoassimilation by Oscillatoria thiebautii in the Caribean Sea. Limnol. Oceanogr 25: 447-456

Loken, M. R. (1980). Simultaneous quantification of Hoechst 33342 and immunofluorescence on viable cells using a fluorescence activated cell sorter. Cytometry 1: 136-141

Makler, M. T., Lee, L. G., Recktenwald, D. (1987). Thiazole Orange: a new dye for Plasmodium species analysis Cytometry 8: 568-570

Mordy, C. W., Carlson, D. J. (1991). An evaluation of fluorescence techniques for measuring DNA and RNA in marine microorganisms. Mar. Ecol. Prog. Ser. 73: 283-293

Paul, J. H., Jeffrey, W. H., DeFlaun, M. F. (1985). Particulate DNA in subtropical oceanic and estuarine planktonic environments. Mar. Biol. 90: 95-101

Paul, J. H., Myers, B. (1982). Fluorometric determinations of DNA in aquatic microorganisms by use of Hoechst 33258 Appl. environ. Microbiol. 43 (6): 1393-1399

Prasad, A. D., DuMouchelle, E., Koniuch, D., Oberleas, D. (1972). A simple fluorometric method for the determination of RNA and DNA in tissues. J. Lab. clin. Med. 80: 598-602

Puiseux-Dao, S. (1981). Cell-cycle events in unicellular algae. In: Platt, $T$ (ed.) Physiological basis of phytoplankton ecology. Can. Bull. Fish. Aquat. Sci. 210: 130-149

Raae, A. J., Opstad, I., Kvenseth, P., Walter, B. I. (1988). RNA, DNA and protein during early development in feeding and starved cod (Gadus morhua L.). Aquaculture, Amsterdam 73: $247-259$

Rizzo, P. J., Nooden, L. D. (1973). Isolation and chemical composition of dinoflagellate nuclei. J. Protozool. 20: $666-673$

Sandhu, L. C., Warters, R. L., Dethlefsen, L. A. (1985). Fluorescence studies of Hoechst 33342 with supercoiled and relaxed plasmid pBR322 DNA. Cytometry 6: 191-194

Shapiro. H. M. (1981). Flow cytometric estimation of DNA and RNA content in intact cells stained with Hoechst 33342 and Pyronin Y Cytometry 2: 143-150

Sober, H. A. (1970). Handbook of biochemistry. Selected data for molecular biology, 2nd edn. Chemical Rubber Company, Cleveland, Ohio

Steiner, R. F., Sternberg, G. (1979). The interaction of Hoechst 33258 with a natural and biosynthetic nucleic acids. Archs Biochem. Biophys. 197: 580-588

Stokke, T., Steen, H. B. (1985). Multiple binding modes for Hoechst 33258 to DNA. J. Histochem. Cytochem. 33: $333-338$

Sutcliffe, W. H., Jr (1970). Relationship between growth rate and ribonucleic acid concentration in some invertebrates. J. Fish. Res. Bd Can. 27. 606-609

Tanke, H. J., Nieuwenhuıs, I. A. B., Koper, G. J. M., Slats, J. C. M., Ploem, J. S. (1980). Flow cytometry of human reticulocytes based on RNA fluorescence. Cytometry 1. 313-320 
Thoresen, S. S., Clayton, J. R., Jr., Dortch, Q. F., Ahmed, S. I. (1983). A rapid technique for the determination of RNA and DNA in marine phytoplankton. J. Plankton Res. 5 (2): 253-261

This article was submitted to the editor
Watson, J. V., Nakeff, A., Chambers, S. H., Smith, P. J. (1985) Flow cytometric fluorescence emission spectrum analysis of Hoechst 33342-stained DNA in chicken thymocytes. Cytometry 6: 310-315

Manuscript first received: October 10, 1990 Revised version accepted: April 12, 1991 